p-ISSN 2089-9858

e-ISSN 2502-3314

\title{
Pengaruh Kombinasi Pupuk Organik dan Anorganik Terhadap Pertumbuhan dan Hasil Padi Gogo Lokal Wakawondu (Oryza sativa L.) yang Diberi Rizobakteri pada Sistem Budidaya Berbeda \\ Combined Effect of Organic and Inorganic Fertilizers on Growth of Local Gogo Rice Wakawondu (Oryza sativa L.) Provided with Rhizobacteria in Different Cultivation Systems
}

\author{
Ilan $\mathrm{Uge}^{1}$, La Ode $\mathrm{Afa}^{2 *}$ dan Andi Nurmas ${ }^{2}$ \\ ${ }^{1}$ Program Studi Magister Agronomi Pascasarjana Universitas Halu Oleo \\ ${ }^{2}$ Jurusan Agroteknologi Fakultas Pertanian Universitas Halu Oleo
}

Diterima: 28 Juni 2021 / Disetujui: 27 Juli 2021

\begin{abstract}
ABSTRAK
Padi gogo lokal Wakawondu merupakan padi asal Buton Utara yang berpotensi dikembangkan secara luas karena memiliki aroma khas "harum", jumlah anakan yang banyak dan antioksidan tinggi. Tujuan penelitian ini yaitu untuk mengetahui pengaruh pupuk organik dan anorganik terhadap pertumbuhan dan hasil padi gogo Wakawondu yang diberi rizobakteri pada sistem budidaya berbeda. Penelitian ini dilaksanakan di lahan percobaan penelitian Kelurahan Kambu Kecamatan Kambu Kota Kendari Provinsi Sulawesi Tenggara dan berlangsung mulai bulan Juni sampai Januari 2021. Penelitian ini menggunakan Rancangan Acak Kelompok (RAK) disusun dalam Split Plot yang terdiri dari Petak Utama: Sistem Budidaya (S) terbagi 2 taraf: Gogo (S1) dan Gogo Rancah (S2); Anak Petak: Pupuk (P) terbagi 4 taraf : Tanpa pupuk (P0); 100\% pupuk organik Bokashi kirinyuh: 10 t.ha $^{-1}(\mathrm{P} 1) ; 100 \%$ pupuk anorganik: Urea $200 \mathrm{~kg}^{-h^{-1}}{ }^{-}$, SP$36100 \mathrm{~kg} \cdot \mathrm{ha}^{-1}$ dan $\mathrm{KCl} 100 \mathrm{~kg} \cdot \mathrm{ha}^{-1}(\mathrm{P} 2)$; dan kombinasi $50 \%$ pupuk organik dan 50\% pupuk anorganik: Bokashi kirinyuh 5 t.ha $^{-1}$ dan Urea $100 \mathrm{~kg} \cdot \mathrm{ha}^{-1}$, SP-36 $50 \mathrm{~kg} \cdot \mathrm{ha}^{-1}$ dan $\mathrm{KCl} 50 \mathrm{~kg} \cdot \mathrm{ha}^{-1}$ (P3) sehingga diperoleh 8 kombinasi perlakuan, setiap unit percobaan diulang 3 kali sebagai kelompok sehingga terdapat 24 petak percobaan. Hasil penelitian menunjukkan bahwa kombinasi sistem gogo rancah dan pemberian $100 \%$ pupuk anorganik dapat meningkatkan tinggi tanaman, jumlah daun, jumlah anakan produktif dan panjang malai. Budidaya padi gogo lokal Wakawondu secara gogo rancah menggunakan pupuk anorganik menunjukkan hasil yang baik dibandingkan sistem budidaya gogo.
\end{abstract}

Kata Kunci: sistem budidaya, pupuk anorganik, pupuk organik, padi gogo lokal, wakawondu.

\section{ABSTRACT}

Wakawondu local upland rice is rice from North Buton that has the potential to be widely developed because it has a distinctive "fragrant" aroma, large number of tillers and high antioxidants. The purpose of this study was to determine the effect of organic and inorganic fertilizers on the growth and yield of Wakawondu upland rice treated with rhizobacteria in different cultivation systems. This research was carried out in the experimental research area of Kambu Village, Kambu District, Kendari City, Southeast Sulawesi Province and took place from June to January 2021. This study used a Randomized Block Design (RAK) arranged in a Split Plot consisting of Main Plots: Cultivation System (S) divided into 2 levels: Gogo (S1) and Gogo Rancah (S2); Sub-plots: Fertilizer (P) divided into 4 levels: No fertilizer (P0); 100\% organic fertilizer Bokashi kirinyuh: 10 t.ha-1 (P1); 100\% inorganic fertilizers: Urea $200 \mathrm{~kg} . \mathrm{ha}-1$, $S P-36100 \mathrm{~kg} . \mathrm{ha}-1$ and $\mathrm{KCl} 100 \mathrm{~kg} . \mathrm{ha}-1$ (P2); and a combination of 50\% organic fertilizer and 50\% inorganic fertilizer: Bokashi kirinyuh 5 t.ha-1 and Urea $100 \mathrm{~kg} . \mathrm{ha}-1, \mathrm{SP}-3650 \mathrm{~kg} \cdot \mathrm{ha}-1$ and $\mathrm{KCl} 50 \mathrm{~kg} . \mathrm{ha}-1$ (P3) so that 8 combined treatment obtained in each experimental unit is repeated 3 times as a group so that there are 24 experimental plots. The results showed that the combination of the upland system and the application of $100 \%$ inorganic fertilizer could increase plant height, number of leaves, number of productive tillers and panicle length. Wakawondu local upland rice cultivation using organic fertilizers showed good results compared to upland cultivation systems.

Keywords: cultivation system, inorganic fertilizer, local upland rice, organic fertilizer, Wakawondu.

\footnotetext{
*Penulis untuk korespondensi, E-mail : laodeafaafa@yahoo.com
} 


\section{PENDAHULUAN}

Padi (Oriza sativa L.) merupakan salah satu bahan pangan yang dikonsumsi oleh sebagian besar penduduk Indonesia. Jumlah penduduk Indonesia bertambah tiap tahun sehingga kebutuhan beras ikut meningkat. Produktivitas padi khususnya padi gogo lokal perlu di tingkatkan mulai dari skala lokal maupun regional. Optimalisasi teknologi budidaya padi gogo lokal potensial perlu dikaji secara berkelanjutan. Salah satu padi gogo lokal potensial yang dikembangkan petani tradisional di Sulawesi Tenggara (Sultra) adalah padi gogo Kultivar Wakawondu. Padi gogo ini dibudidayakan secara luas oleh petani Buton Utara dengan sistem organik. Padi gogo lokal Wakawondu merupakan padi asal Buton Utara yang memiliki aroma yang khas "harum", jumlah anakan yang banyak, antioksidan tinggi, tetapi rentan penyakit hawar daun dan memiliki umur panen yang lama (Afa et al., 2018; Kadidaa et al., 2017; Sadimantara et al., 2011; Sadimantara et al., 2012; Sarwanto et al., 2018). Produktivitas padi Wakawondu pada skala petani masih sangat rendah (1-2 t.ha $\left.{ }^{-1}\right)$ karena teknologi budidaya belum optimal.

Berbagai teknik budidaya yang bisa diadopsi masyarakat petani dalam mengoptimalkan produksi antara lain penggunaan pupuk dan pengaturan sistem budidaya. Manajemen pupuk dengan interaksi pupuk organik dan pupuk anorganik dapat berperan penting dalam meningkatkan dan mempertahankan produktivitas tanaman (Mondal et al., 2016). Upaya rekayasa lingkungan tumbuh diperlukan untuk memperbaiki kesuburan tanah seperti pemupukan berbasis kecukupan hara tanaman melalui pemanfaatan bahan organik dan anorganik secara berimbang dan perlakuan benih pratanam (Usman et al., 2004); Barus, 2008; Norsalis, 2011; Padmanabha et al. 2014). Hal ini merupakan cara terbaik untuk menjaga kesuburan tanah (Mungai et al., 2009) dan dapat mengurangi kerusakan yang disebabkan oleh pupuk kimia (Han et al., 2016). Pemberian pupuk organik bersama dengan pupuk anorganik sebagai komplemen dapat meningkatkan produktivitas tanah dan tanaman (Warankar et al., 2020).

Umur panen yang lama merupakan masalah klasik dalam budidaya padi gogo lokal, sehingga perlu solusi alternatif untuk memperpendek umur panen. Padi merupakan tanaman semi aquatik (suka air), sehingga penerapan sistem budidaya gogo rancah diyakini mampu mempercepat umur panen dan memaksimalkan hasil padi gogo Wakawondu. Pengaturan sistem budidaya dilakukan untuk mengantisipasi kekurangan air tanaman pada awal fase generatif. Tanaman padi yang dibiarkan tidak tergenang selama fase vegetatif diyakini dapat meningkatkan pembentukan jumlah anakan. Suplai air yang baik pada awal fase generatif (awal masa bunting) tanaman padi diyakini mampu mengoptimalkan perkembangan bunga dan pengisisan biji Integrasi pupuk organik dan anorganik pada sistem budidaya gogo dan gogo rancah merupakan teknik budidaya yang tepat untuk mengatasi kekurangan air dan rendahnya kesuburan tanah. Disamping itu, untuk memaksimalkan hasil dan mengantisipasi serangan penyakit maka diperlukan perlakuan benih pratanam menggunakan agen hayati.

Isolat rizobakteri mampu meningkatkan pertumbuhan dan sebagai penyedia hara atau biofertilizer (Sutariati et al., 2011). Agen hayati seperti bakteri Pseudomonas sp., dapat menghasilkan fitohormon diantaranya IAA, sitokinin dan giberelin (Adesemoye et al., 2008), serta mampu melarutkan fosfat dan memfiksasi nitrogen (Sutariati dan Wahab, 2012; Afa et al., 2020). Arsanti (2017), menyatakan bahwa isolat rizobakteri asal tanaman padi gogo lokal Sultra yang memiliki kemampuan terbaik melarutkan fosfat adalah KNW11 (asal Konawe) dan KLKU02 (asal Kolaka Utara). Oleh karena itu, penelitian ini perlu dilakukan untuk mengetahui pengaruh integrasi pupuk organik dan anorganik terhadap pertumbuhan dan hasil padi gogo lokal Wakawondu (Oryza sativa L.) yang diberi Rizobakteri pada sistem budidaya gogo dan gogo rancah.

\section{BAHAN DAN METODE}

\section{Lokasi dan Waktu Penelitian}

Penelitian ini dilaksanakan di lahan percobaan Kelurahan Kambu Kecamatan Kambu Kota Kendari Provinsi Sulawesi Tenggara dan di Laboratorium Agroteknologi Unit Agronomi Fakultas Pertanian Universitas Halu Oleo Kota Kendari. Lokasi penelitian terletak pada kordinat 04 ${ }^{0} \mathrm{LS}$ dan $122,41{ }^{0} \mathrm{BT}$ dengan ketinggian tempat \pm 13,33 m dpl. Penelitian berlangsung mulai bulan Juni 2020 sampai Januari 2021.

\section{Bahan dan Alat}

Bahan yang digunakan pada penelitian adalah benih padi gogo kultivar Wakawondu asal Buton Utara Sulawesi Tenggara, kertas label, pupuk bokashi kirinyuh, isolat rizobakteri indigenous KNW11 (koleksi Prof. Dr. Ir. Gusti Ayu Kade Sutariati, M.Si), Aquades, alkohol $70 \%$, plastik wrap, kertas label, spiritus, agar-agar, Tripthic Soy 
Broth (TSB), amplop dan arang sekam padi. Alat yang digunakan yaitu pacul, plastik label, gunting, timbangan analitik, oven, kamera, mistar ukur, cawan petri, gelas ukur, labu erlenmeyer, shaker, jarum ose, botol scoot, lampu bunsin, laminar air flow cabinet, auto clave, hot plate dan alat menulis.

\section{Rancangan Penelitian}

Rancangan penelitian yang digunakan yaitu Rancangan Acak Kelompok (RAK) dengan pola Split Plot (petak terbagi) yang terdiri dari 2 faktor yaitu Petak Utama: Sistem Budidaya (S) terdiri dari 2 taraf: Gogo (S1) dan Gogo Rancah (S2); Anak Petak: Pupuk (P) terdiri dari 4 taraf : Tanpa pupuk $\left(\mathrm{P}_{0}\right)$; Pemberian $100 \%$ pupuk organik $(\mathrm{P} 1)$ : Bokashi kirinyuh 10 t.ha $^{-1 ;}$ Pemberian $100 \%$ pupuk an-organik (P2): Urea $200 \mathrm{~kg}^{-h^{-1}}$, SP-36 100 kg.ha ${ }^{-1}$ dan $\mathrm{KCl} 100 \mathrm{~kg} \cdot \mathrm{ha}^{-1}$; Kombinasi $50 \%$ pupuk organik dan 50\% pupuk an-organik (P3): Bokashi kirinyuh 5 t.ha $^{-1}$ atau dan Urea 100 kg.ha ${ }^{-1}$, SP-36 50 kg.ha ${ }^{-1}$ dan KCl 50 kg.ha ${ }^{-1}$. Diperoleh 8 kombinasi perlakuan, setiap unit percobaan diulang 3 kali sebagai kelompok sehingga terdapat 24 petak percobaan.

\section{Prosedur Penelitian}

\section{Persiapan Pupuk}

Pupuk yang digunakan adalah pupuk bokashi kirinyuh yang terbuat dari campuran kirinyuh $30 \mathrm{~kg}$ (dipotong-potong $\pm 2 \mathrm{~cm}$ ), kotoran ayam $25 \mathrm{~kg}$ dan dedak $15 \mathrm{~kg}$ yang sudah tercampur merata dengan larutan. Larutan terbuat dari EM4 $(100 \mathrm{ml})$ dan gula pasir $(100 \mathrm{~g})$ yang dicampur dengan 20 liter air. Bahan yang telah tercampur selanjutnya ditutup terpal dan diinkubasi selama 1 bulan, dengan suhu bahan bokashi maksimal $50{ }^{\circ} \mathrm{C}$ untuk menghasilkan pupuk yang baik.

\section{Persiapan Lahan Percobaan}

Persiapan lahan didahului dengan pengolahan tanah untuk sistem budidaya gogo rancah dan dilanjutkan untuk sistem budidaya gogo rancah. Pengolahan tanah pada sistem budidaya gogo dilakukan dua kali menggunakan pacul agar diperoleh bedengan atau petakan tanah yang baik. Pengolahan tanah untuk gogo rancah dilakukan dengan tahapan: pengolahan tanah menggunakan pacul, penggenangan (inkubasi) selama \pm 1 minggu, kemudian dilakukan pelumpuran dan diikuti perataan petakan.

\section{Persiapan Suspensi Rizobakteri KNW11 dan Perlakuan Bahan Tanaman}

Tahapan persiapan suspensi isolat rizobakteri KNW11 yaitu pembuatan media tumbuh bakteri, pembuatan TSB cair, pemurnian dan perbanyakan rizobakteri dan suspensi rizobakteri. Pembuatan suspensi rizobakteri yaitu digunakan 3 buah cawan yang memiliki koloni bakteri yang baik. Koloni rizobakteri di suspensikan dalam aquades steril dengan volume $50 \mathrm{ml}$ hingga kerapatan populasi $10^{9} \mathrm{CFU} / \mathrm{ml}$. Volume suspensi dalam erlenmeyer yang diperoleh adalah $125 \mathrm{ml}$. Rizobakteri tersebut kemudian ditambahkan dengan $5 \mathrm{ml}$ TSB cair dan ditambahkan aquades steril 20 $\mathrm{ml}$ sehingga total keseluruhan menjadi $150 \mathrm{ml}$. Kemudian benih padi yang memiliki ukuran yang relatif seragam didisinfeksi dengan menggunakan $\mathrm{NaCI} 0 \quad(5,25 \%)$, kemudian direndam dengan alkohol $70 \%$ selama 3 menit. Setelah itu dicuci dengan aquades sebanyak 3 kali dan dikering anginkan dalam laminar air flow cabinet selama 60 menit. Kemudian benih padi dimasukan dalam botol erlenmeyer berisikan larutan suspensi rizobakteri. Benih diinkubasi pada ruang dengan suhu kamar selama 24 jam, kemudian benih disemai dalam box berisi arang sekam padi selama 7 hari.

\section{Penanaman}

Penanaman dilakukan dengan cara ditugal sedalam $\pm 3 \mathrm{~cm}$ dengan jumlah 2 bibit per lubang tanam. Jarak tanam $25 \times 25 \mathrm{~cm}$ dengan luas petakan $0,25 \times 0,75 \mathrm{~m}$.

\section{Pemupukan}

Pupuk yang digunakan yaitu pupuk organik bokashi kirinyuh dan pupuk anorganik (pupuk Urea, SP-36 dan $\mathrm{KCl}$ ) serta kombinasinya. Aplikasi pupuk bokashi kirinyuh ke petak percobaan dilakukan 1 minggu sebelum tanam dengan cara dicampur dengan tanah pada masing-masing petak percobaan sesuai perlakuan., Sedangkan pupuk Urea, SP-36 dan $\mathrm{KCl}$ diberikan saat tanam dengan cara dibuat bentuk larikan disamping tanaman, kemudian ditutup kembali dengan tanah.

Pupuk Urea diberikan 2 kali yaitu setengah dosis diberikan saat tanam dan setengah dosis diberikan pada umur 8 MST.

\section{Pemeliharaan}

Tindakan pemeliharaan tanaman meliputi penyulaman, pengairan, penyiangan dan pengendalian hama tanaman. Penyulaman dilakukan dengan mengganti tanaman yang kurang baik pertumbuhannya. Pengairan dan penyiraman disesuaikan dengan perlakuan sistem budidaya. Pada budidaya gogo, penyiraman dilakukan apabila tidak turun hujan dan kondisi air tetap dipertahankan pada kapasitas lapang. Pada budidaya gogo rancah, tahap pertumbuhan awal (fase vegetatif) kondisi petakan sama degan kondisi gogo namun setelah akhir fase vegetatif dilakukan 
penggenangan setinggi $\pm 2 \mathrm{~cm}$. Penyiangan dilakukan secara manual dengan cara mencabut gulma atau tanaman pengganggu yang tumbuh pada petak percobaan menggunakan tangan maupun tembilang. Pengendalian hama dilakukan secara optimal baik secara manual maupun menggunakan bahan kimia (Furadan).

\section{Panen}

Panen dilakukan dengan melihat tandatanda minimal $85 \%$ gabah sudah menguning. Panen dilakukan dengan cara memotong tangkai malai padi yang terletak tepat di bawah pangkal daun bendera menggunakan gunting.

\section{Variabel Penelitian}

Variabel yang diamati yaitu tinggi tanaman, jumlah anakan maksimum dan jumlah daun, jumlah anakan produktif, umur berbunga, luas daun bendera, panjang malai, total gabah per malai, persentase gabah isi dan bobot 1000 butir. Pengamatann pertumbuhan dilakukan pada akhir vegetatif dan komponen hasil dilakukan setelah panen.

\section{Analisis Data}

Data hasil pengamatan dianalisis dengan sidik ragam dan pabila menunjukkan pengaruh nyata $\left(\mathrm{F}_{\text {hitung }}>\mathrm{F}_{\text {tabel }}\right)$ maka dilanjutkan dengan Uji Jarak Berganda Duncan (Duncan's Multiple Range Test) pada taraf nyata $\alpha=0,05$.

\section{HASIL DAN PEMBAHASAN}

Hasil sidik ragam menunjukkan bahwa perlakuan interaksi dan mandiri perlakuan sistem budidaya serta pupuk dapat memberikan pengaruh terhadap pertumbuhan dan hasil padi gogo lokal Wakawondu yang diberi rizobakteri indigeonus KNW11. Perlakuan interaksi menunjukkan pengaruh nyata terhadap tinggi tanaman, jumlah daun, jumlah anakan produktif, panjang malai dan bobot gabah kering per malai. Perlakuan pupuk secara mandiri menunjukkan pengaruh nyata terhadap tinggi tanaman, jumlah daun, jumlah anakan maksimum, jumlah anakan produktif, umur berbunga, luas daun bendera, panjang malai, total gabah per malai, persentase gabah isi dan bobot 1000 bulir. Perlakuan sistem budidaya secara mandiri tidak memberikan pengaruh terhadap pertumbuhan padi, namun memberikan pengaruh nyata terhadap jumlah anakan produktif, umur berbunga, panjang malai dan bobot 1000 bulir.

\section{Tinggi Tanaman (cm)}

Hasil uji DMRT interaksi perlakuan sistem budidaya dan pupuk terhadap tinggi tanaman padi gogo lokal Wakawondu (Tabel 1) menunjukkan rata-rata tertinggi pada kombinasi sistem budidaya gogo rancah dengan pemberian $100 \%$ pupuk anorganik $(121,69 \mathrm{~cm})$. Pemberian pupuk yang sama juga memberikan pengaruh terbaik pada sistem budidaya gogo $(94,26 \mathrm{~cm})$ dan tidak berbeda nyata dengan pemberian 100 pupuk organik bokashi $(91,20 \mathrm{~cm})$ dan kombinasi pemberian $50 \%$ organik $+\quad 50 \%$ anorganik $(89,34 \mathrm{~cm})$. Rata-rata pertumbuhan tinggi tanaman terendah ditunjukkan pada perlakuan tanpa pupuk. Hal ini diduga karena pemberian $100 \%$ pupuk anorganik pada sistem bididaya gogo rancah memiliki nutrisi $(\mathrm{N}, \mathrm{P}, \mathrm{K})$ dan air yang cukup untuk tanaman.

Tabel 1. Hasil uji pengaruh interaksi sistem budidaya dan pupuk terhadap tinggi tanaman $(\mathrm{cm})$ padi lokal Wakawondu akhir vegetatif

\begin{tabular}{lccc}
\hline Perlakuan & \multicolumn{2}{c}{ Sistem Budidaya } & \multirow{2}{*}{ Rata-rata } \\
\cline { 1 - 2 } Pupuk & Gogo & Gogo Rancah & \\
\cline { 1 - 2 } Tanpa Pupuk & $73,94^{\mathrm{b}}{ }_{\mathrm{q}}$ & $83,93^{\mathrm{d}}{ }_{\mathrm{p}}$ & $78,93^{\mathrm{c}}$ \\
$100 \%$ pupuk organik & $91,20_{\mathrm{q}}^{\mathrm{a}}$ & $102,58^{\mathrm{c}}{ }_{\mathrm{p}}$ & $96,89^{\mathrm{b}}$ \\
$100 \%$ pupuk anorganik & $94,26^{\mathrm{a}}{ }_{\mathrm{q}}$ & $121,69^{\mathrm{a}}{ }_{\mathrm{p}}$ & $107,98^{\mathrm{a}}$ \\
Kombinasi $(50 \%$ organik $+50 \%$ anorganik) & $89,34_{\mathrm{q}}^{\mathrm{a}}$ & $110,94^{\mathrm{b}}{ }_{\mathrm{p}}$ & $100,14^{\mathrm{b}}$ \\
\hline Rata-rata & $87,19^{\mathrm{b}}$ & $104,78^{\mathrm{a}}$ & \\
\hline
\end{tabular}

Keterangan : Angka yang diikuti huruf yang tidak sama pada baris $(\mathrm{p}, \mathrm{q})$ atau kolom $(\mathrm{a}, \mathrm{b}, \mathrm{c}, \mathrm{d})$ yang sama berbeda nyata berdasarkan uji DMRT pada $\alpha=0.05$.

Pupuk anorganik tersedia dalam bentuk ion dan mudah larut bersama air sehingga cepat diserap oleh akar tanaman padi untuk pertumbuhan dan perkembangan tanaman (Das dan Mandal, 2015). Pada fase vegetatif, tanaman padi memerlukan unsur Nitrogen dalam bentuk Nitrat (N03-) atau 
ammonium $\left(\mathrm{NH}^{+}\right)$yang cukup untuk proses pembelahan dan pemanjangan sel. Darmawan dan Asmuliani R. (2019) menyatakan bahwa pemberian pupuk kedalam tanah dapat meningkatkan pertumbuhan vegetatif tanaman karena unsur nitrogen lebih banyak diserap untuk meningkatkan pertumbuhan vegetatif tanaman. Disamping itu, genangan disekitar akar pada akhir fase vegetatif juga menyebabkan pertambahan tinggi tanaman karena adanya adaptasi dengan melakukan pembesaran atau pemanjangan ruas batang sebagai tempat cadangan oksigen. Menurut Yullianida et al. (2015) menyatakan bahwa tanaman yang terendam air akan berdaptasi dengan melakukan pemanjangan batang untuk terhindar dari kondisi anaerob.

\section{Jumlah Anakan Maksimum (anakan)}

Hasil uji DMRT pengaruh mandiri perlakuan pupuk terhadap jumlah anakan padi gogo lokal Wakawondu (Tabel 2) menunjukkan rata-rata nilai tertinggi pada kombinasi $50 \%$ organik bokashi dan anorganik (10,67 anakan). Perlakuan kombinasi $50 \%$ organik bokashi dan anorganik menunjukan pengaruh yang sama dengan perlakuan $100 \%$ pupuk anorganik (10,22 anakan). Jumlah nakan terendah secara keseluruhan diperoleh pada perlakuan tanpa pemberian pupuk (5,78 anakan). Pemberian kombinasi $50 \%$ organik bokashi dan anorganik mampu menambah dan melengkapi unsur hara yang yang dibutuhkan untuk pertumbuhan tanaman. Kandungan unsur hara makro $(\mathrm{N}, \mathrm{P}, \mathrm{K})$ yang berasal dari kombinasi tersebut dapat membantu tanaman dalam proses fotosintesis. Proses fotosintesis yang baik dapat menghasilkan pembentukan anakan padi Wakawondu yang maksimal. Hasil ini didukung oleh Agegnehu et al. (2016) menjelaskan bahwa tanah yang diberi kombinasi bahan organik dan pupuk anorganik dapat meningkatkan kadar air tanah, kandungan $\mathrm{P}$ tersedia, Ca dapat ditukar, dan KTK tanah. Selanjutnya penelitian Li et al. (2017) menjelaskan penggunakan kombinasi pupuk anorganik dan organik dapat menghasilkan sifat kimia tanah yang baik untuk tanaman maupun untuk mikroba tanah, sehingga diyakini mampu memenuhi kebutuhan tanaman.

Tabel 2. Hasil uji pengaruh interaksi sistem budidaya dan pupuk terhadap jumlah anakan maksimum (anakan) Daftar Pustaka padi lokal Wakawondu

\begin{tabular}{lc}
\hline Perlakuan & Rata-rata Jumlah Anakan (anakan) \\
\hline Tanpa Pupuk & $5,78^{\mathrm{c}}$ \\
$100 \%$ pupuk organik & $8,95^{\mathrm{b}}$ \\
$100 \%$ pupuk anorganik & $10,22^{\mathrm{a}}$ \\
Kombinasi (50\% organik $+50 \%$ anorganik) & $10,67^{\mathrm{a}}$ \\
\hline Keterangan: Angka yang diikuti huruf yang tidak sama pada kolom $(\mathrm{a}, \mathrm{b}, \mathrm{c})$ yang sama berbeda nyata \\
\multicolumn{2}{c}{ berdasarkan uji DMRT pada $\alpha=0.05}$.
\end{tabular}

\section{Jumlah Daun (helai)}

Daun merupakan salah satu organ penting tanaman padi yang berfungsi sebagai tempat terjadinya fotosintesis. Jumlah daun berhubungan dengan jumlah anakan, dimana semakin banyak anakan yang terbentuk maka semakin banyak jumlah daun sehingga dapat meningkatkan hasil fotosintesis. Hasil uji DMRT pengaruh interaksi perlakuan sistem budidaya dan pupuk terhadap jumlah daun padi gogo lokal Wakawondu (Tabel 3) menunjukkan rata-rata jumlah daun terbanyak pada kombinasi perlakuan sistem budidaya gogo rancah dengan pemberian $100 \%$ anorganik $(39,00$ helai). Selanjutnya diikuti kombinasi sistem budidaya gogo dengan pemberian pupuk organik bokashi $(33,45$ helai) dan tidak berbeda nyata dengan pemberian $100 \%$ anorganik (31,78 helai) dan $50 \%$ organik dan anorganik $(30,67$ helai). Namun, rata-rata jumlah daun terendah terdapat pada perlakuan tanpa menggunakan pupuk. Tanaman padi merupakan jenis tanaman semi aquatik sehingga pada kondisi yang cukup air dan unsur hara, akan menghasilkan jumlah daun yang banyak. Hal ini disebabkan karena pemberian pupuk anorganik (NPK) secara langsung dapat menyediakan unsur hara dalam bentuk ion yang mudah larut dalam air sehingga lebih cepat diserap tanaman (Rachmadani et al., 2014).

Pemberian bahan organik bokashi pada lahan budidaya gogo dapat memperbaiki struktur tanah dan mampu mengikat air sehingga akar dengan mudah menembus tanah. Roidah (2013) menjelaskan bahwa pupuk organik dapat memperbaiki kondisi tanah dan dapat mensuplai air dan unsur hara sehingga mampu meningkatkan pertumbuhan luas daun. Unsur nitrogen merupkan 
unsur yang banyak dibutuhkan dalam perbanyakan jumlah daun. Hal ini sesuai dengan pernyataan Ismunadji dan Roechan dalam Laila (2017) bahwa pembentukan anakan, tinggi tanaman, luas daun dan jumlah gabah dipengaruhi oleh ketersediaan nitrogen.

Tabel 3. Hasil uji pengaruh interaksi sistem budidaya dan pupuk terhadap jumlah daun (helai) padi lokal Wakawondu akhir vegetatif

\begin{tabular}{lccc}
\hline Perlakuan & \multicolumn{2}{c}{ Sistem Budidaya } & \multirow{2}{*}{ Rata-rata } \\
\cline { 1 - 3 } Pupuk & Gogo & Gogo Rancah & \\
\cline { 1 - 2 } Tanpa Pupuk & $20,00^{\mathrm{b}}{ }_{\mathrm{p}}$ & $19,67^{\mathrm{d}}$ & \multirow{2}{*}{$19,84^{\mathrm{c}}$} \\
$100 \%$ pupuk organik & $34,45_{\mathrm{p}}^{\mathrm{a}}$ & $27,11_{\mathrm{q}}^{\mathrm{c}}$ & $30,78^{\mathrm{b}}$ \\
$100 \%$ pupuk anorganik & $31,78_{\mathrm{q}}^{\mathrm{a}}$ & $39,00^{\mathrm{a}}$ & $37,39^{\mathrm{a}}$ \\
Kombinasi (50\% organik $+50 \%$ anorganik) & $29,67^{\mathrm{a}}{ }_{\mathrm{q}}$ & $35,55^{\mathrm{b}}$ & $32,61^{\mathrm{ab}}$ \\
\hline Rata-rata & $28,72 \mathrm{a}$ & $30,33 \mathrm{a}$ & \\
\hline
\end{tabular}

Keterangan : Angka yang diikuti huruf yang tidak sama pada baris $(\mathrm{p}, \mathrm{q})$ atau kolom $(\mathrm{a}, \mathrm{b}, \mathrm{c}, \mathrm{d})$ yang sama berbeda nyata berdasarkan uji DMRT pada $\alpha=0.05$.

\section{Jumlah Anakan Produktif}

Hasil uji DMRT interaksi perlakuan sistem budidaya dan pupuk terhadap jumlah anakan produktif padi gogo lokal Wakawondu (Tabel 4) menunjukkan rata-rata nilai tertinggi pada kombinasi perlakuan sistem budidaya gogo rancah dengan pemberian $100 \%$ pupuk anorganik $(8,56$ anakan) dan tidak berbeda nyata dengan kombinasi $50 \%$ organik bokashi $+50 \%$ anorganik. Selanjutnya pada sistem budidaya gogo, rata-rata tertinggi diperoleh pada perlakuan $100 \%$ organik (6,33 anakan), namun menunjukkan pengaruh yang tidak berbeda dengan perlakuan 100 pupuk anorganik (6,00 anakan) dan kombinasinya $(6,22$ anakan). Banyaknya jumlah anakan produktif ditentukan oleh jumlah anakan maksimum. Jumlah anakan maksimum menunjukkan nilai tertinggi pada perlakuan kombinasi $50 \%$ pupuk organik bokashi dan anorganik (Tabel 2) sehingga akan meningkatkan jumlah anakan produktif. Hal ini disebabkan karena pemberian pupuk anorganik pada sistem budidaya gogo rancah dapat mensuplai nutrisi dan air yang cukup untuk menghasilkan malai. Disamping itu, pemberian pupuk organik pada sistem gogo mampu memenuhi kebutuhan unsur hara pada saat pembentukan anakan. Tufaila et al. (2014) menyatakan bahwa tanaman padi dapat menghasilkan anakan produktif yang optimal karena pemberian pupuk bokhasi yang mampu mengaktifkan aktivitas sel-sel jaringan meristematik tanaman. Kurangnya unsur hara dan air dapat proses fotosintesis pada tanaman padi Wakawondu menyebabkan anakan tidak menghasilkan malai.

Tabel 4. Hasil uji pengaruh interaksi sistem budidaya dan pupuk terhadap jumlah anakan produktif (anakan) padi lokal Wakawondu

\begin{tabular}{lccc}
\hline Perlakuan & \multicolumn{2}{c}{ Sistem Budidaya } & \multirow{2}{*}{ Rata-rata } \\
\cline { 1 - 3 } Pupuk & Gogo & Gora Rancah & \\
\cline { 1 - 2 } Tanpa Pupuk & $3,44^{\mathrm{b}}{ }_{\mathrm{p}}$ & $3,78^{\mathrm{c}}{ }_{\mathrm{p}}$ & $3,61^{\mathrm{c}}$ \\
$100 \%$ pupuk organik & $6,33_{\mathrm{p}}^{\mathrm{a}}$ & $6,00^{\mathrm{b}}$ & $6,33^{\mathrm{b}}$ \\
$100 \%$ pupuk anorganik & $6,00^{\mathrm{a}}{ }_{\mathrm{q}}$ & $8,56^{\mathrm{a}}$ & $7,89^{\mathrm{a}}$ \\
Kombinasi (50\% organik $+50 \%$ anorganik) & $6,22^{\mathrm{a}}{ }_{\mathrm{q}}$ & $8,44^{\mathrm{a}}$ & $7,22^{\mathrm{a}}$ \\
\hline Rata-rata & $5,56^{\mathrm{b}}$ & $6,97^{\mathrm{a}}$ & \\
\hline
\end{tabular}

Keterangan: Angka yang diikuti huruf yang tidak sama pada baris $(p, q)$ atau kolom $(a, b, c)$ yang sama berbeda nyata berdasarkan uji DMRT pada $\alpha=0.05$. 


\section{Umur Berbunga}

Hasil uji DMRT pengaruh mandiri perlakuan sistem budidaya dan pupuk terhadap umur berbunga padi gogo lokal Wakanwodu (Tabel 5) menunjukkan rata-rata umur paling lama diperoleh pada sistem budidaya gogo (122 hari) dan paling cepat pada sistem budidaya gogo rancah (101 hari). Perbedaan umur tanaman dapat disebabkan karena pengaruh faktor lingkungan sistem budidaya berbeda. Fakor lingkungan budidaya seperti ketersediaan air dan oksigen dalam tanah berperan penting dalam pembungaan dan pematangan gabah. dapat membantu tanaman padi gogo dalam proses fotosintesis terutama pada fase pembungaan dan pengisisan biji. Kurangnya suplai air dari dalam tanah menyebabkan bunga tidak berkembang dengan baik (Sikuku et al., 2010). Sedangkan pengaruh mandiri pupuk menunjukkan pengaruh terbaik pada kombinasi pemberian 50\% puk organik dan anorganik. Hal ini disebabkan karena kombinasi kandungan nutrisi dari bahan organik bokasi dan anorganik cenderung memberikan pengaruh yang kompleks dalam memenuhi kebutuhan tanaman dibandingkan perlakuan lainnya.

Tabel 5. Hasil uji pengaruh mandiri sistem budidaya dan pupuk terhadap umur berbunga (hari) padi lokal Wakawondu

\begin{tabular}{lc}
\hline Perlakuan & Rata-rata Umur Berbunga (hari) \\
\hline Gogo & $122,33^{\mathrm{a}}$ \\
Gora Rancah & $101,83^{\mathrm{b}}$ \\
\hline Tanpa Pupuk & $116,17^{\mathrm{a}}$ \\
$100 \%$ pupuk organik & $110,50^{\mathrm{b}}$ \\
$100 \%$ pupuk anorganik & $111,83^{\mathrm{b}}$ \\
Kombinasi $(50 \%$ organik $+50 \%$ anorganik) & $109,83^{\mathrm{b}}$ \\
\hline
\end{tabular}

Keterangan: Angka yang diikuti huruf yang tidak sama pada kolom $(\mathrm{a}, \mathrm{b})$ yang sama berbeda nyata berdasarkan uji DMRT pada $\alpha=0.05$.

\section{Luas Daun Bendera $\left(\mathrm{cm}^{2}\right)$}

Hasil uji DMRT pada pengaruh mandiri perlakuan pupuk terhadap luas daun bendera padi gogo lokal Wakawondu (Tabel 6) menunjukkan rata-rata nilai tertinggi pada perlakuan $100 \%$ pupuk anorganik $\left(27,76 \mathrm{~cm}^{2}\right)$ dan menunjukkan pengaruh yang sama dengan $100 \%$ pupuk anorganik $(25,04$ $\mathrm{cm}^{2}$ ) dan kombinasi $50 \%$ organik $+50 \%$ anorganik $\left(25,37 \mathrm{~cm}^{2}\right)$. Perlakuan tanpa menggunakan pupuk menunjukkan hasil luas daun bendera terendah $\left(20,42 \mathrm{~cm}^{2}\right)$ dan berbeda nyata dengan perlakuan lainnya. Daun bendera yang luas menunjukkan adanya konsumsi oksigen dan zat-zat makanan atau nutrisi cukup tersedia dalam tanah sehingga mempermudah tanaman dalam melakukan hasil fotosintesis. Proses fotosintesis ini dapat menghasilkan karbohidrat dan $\mathrm{O}_{2}$ dengan memanfaatkan $\mathrm{CO} 2$, air dan cahaya matahari yang ada di alam untuk kelangsungan hidup tanaman (Hüve et al. 2019; Susanto $d k k$. 2020; Tombesi et al. 2019), khususnya pada pembelahan dan pemanjangan sel pada daun bendera.

Tabel 6.Hasil uji pengaruh mandiri pupuk terhadap luas daun bendera $\left(\mathrm{cm}^{2}\right)$ padi lokal Wakawondu

\begin{tabular}{lc}
\hline Perlakuan & Rata-rata Luas Daun Bendera $\left(\mathrm{cm}^{2}\right)$ \\
\hline Tanpa Pupuk & $20,42^{\mathrm{b}}$ \\
$100 \%$ pupuk organik & $25,04^{\mathrm{a}}$ \\
$100 \%$ pupuk anorganik & $27,76^{\mathrm{a}}$ \\
Kombinasi $(50 \%$ organik $+50 \%$ anorganik) & $25,37^{\mathrm{a}}$ \\
\hline
\end{tabular}

Keterangan: Angka yang diikuti huruf yang tidak sama pada kolom $(\mathrm{a}, \mathrm{b})$ yang sama berbeda nyata berdasarkan uji DMRT pada $\alpha=0.05$. 


\section{Panjang Malai (cm)}

Hasil uji DMRT interaksi perlakuan sistem budidaya dan pupuk terhadap panjang malai padi gogo lokal Wakawondu (Tabel 7) menunjukkan rata-rata tertinggi pada kombinasi sistem budidaya gogo rancah dan pemberian $100 \%$ pupuk anorganik $(24,25 \mathrm{~cm})$. Sedangkan pada sistem budidaya gogo tidak menunjukkan interakasi yang nyata dengan pemberian pupuk. Panjang malai berhubungan erat dengan komponen jumlah gabah karena malai yang panjang dengan total gabah per malai yang banyak dapat meningkatkan kepadatan gabah (Zang et al., 2010). Berdasarkan hasil penelitian menunjukkan rata-rata panjang malai masih tergolong sedang yaitu 20-30 (Makarim et al., 2009). Hal ini disebabkan karena pemberian pupuk anorganik (NPK) pada sistem gogo rancah dapat menyebabkan pembentukan malai menjadi baik karena tanaman tidak mengalami kekurangan unsur hara dan cekaman air.

Tabel 7. Hasil uji pengaruh interaksi sistem budidaya dan pupuk terhadap panjang malai $(\mathrm{cm})$ padi lokal Wakawondu

\begin{tabular}{lccc}
\hline Perlakuan & \multicolumn{2}{c}{ Sistem Budidaya } & \multirow{2}{*}{ Rata-rata } \\
\cline { 1 - 2 } Pupuk & Gogo & Gogo Rancah & \\
\cline { 1 - 2 } Tanpa Pupuk & $19,85^{\mathrm{a}}{ }_{\mathrm{p}}$ & $19,83^{\mathrm{c}}{ }_{\mathrm{p}}$ & $19,84^{\mathrm{c}}$ \\
$100 \%$ pupuk organik & $20,80^{\mathrm{a}}{ }_{\mathrm{q}}$ & $21,98^{\mathrm{b}}{ }_{\mathrm{p}}$ & $21,39^{\mathrm{b}}$ \\
$100 \%$ pupuk anorganik & $20,92^{\mathrm{a}}{ }_{\mathrm{q}}$ & $24,25^{\mathrm{a}}{ }_{\mathrm{p}}$ & $22,59^{\mathrm{a}}$ \\
Kombinasi (50\% organik $+50 \%$ anorganik) & $20,49^{\mathrm{a}}{ }_{\mathrm{q}}$ & $22,69^{\mathrm{b}}{ }_{\mathrm{p}}$ & $21,59^{\mathrm{ab}}$ \\
\hline Rata-rata & $20,51^{\mathrm{b}}$ & $22,19^{\mathrm{a}}$ & \\
\hline
\end{tabular}

Keterangan: Angka yang diikuti huruf yang tidak sama pada baris (p,q) atau kolom (a,b,c) yang sama berbeda nyata berdasarkan uji DMRT pada $\alpha=0.05$.

\section{Total Gabah Per Malai (bulir)}

Hasil uji DMRT pengaruh mandiri perlakuan pupuk terhadap total gabah per malai padi gogo lokal Wakawondu (Tabel 8) menunjukkan perlakuan terbaik pada pemberian $100 \%$ pupuk anorganik dan tidak berbeda dengan perlakuan pupuk lainnya. Sedangkan rata-rata total gabh terendah diperoleh pada perlakuan tanpa pupuk. Total gabah per malai berhubungan dengan panjang malai tanaman padi. Malai yang panjang dapat memberi peluang untuk menghasilkan gabah yang banyak. Hal ini disebabkan karena pupuk anorganik (urea, SP-36 dan $\mathrm{KCl}$ ) mampu mengoptimlakan proses fotosintesis sehingga hasil fotosintat dapat ditranslokasikan dengan baik untuk pembentukan gabah. Pembentukan gabah sangat ditentukan oleh ketersediaan unsur hara $\mathrm{P}$ sehingga diduga pemberian $100 \%$ anorganik mampu mencukupi unsur hara tersebut dalam tanah. Hal ini sesuai didukung dengan pernyataan Reddy et al. (2021) bahwa pemberian pupuk anorganik dapat menghasilkan kandungan $\mathrm{P}$ tersedia dalam tanah yang lebih tinggi dari pada sumber bahan organik.

Tabel 8. Hasil uji pengaruh mandiri perlakuan pupuk terhadap total gabah per malai (bulir) padi lokal Wakawondu

\begin{tabular}{lc}
\hline Perlakuan & Rata-rata Total Gabah Per Malai (bulir) \\
\hline Tanpa Pupuk & $97,70^{\mathrm{b}}$ \\
$100 \%$ pupuk organik & $108,63^{\mathrm{a}}$ \\
$100 \%$ pupuk anorganik & $110,80^{\mathrm{a}}$ \\
Kombinasi (50\% organik $+50 \%$ anorganik) & $109,00^{\mathrm{a}}$ \\
\hline
\end{tabular}

Keterangan : Angka yang diikuti huruf yang tidak sama pada kolom $(a, b)$ yang sama berbeda nyata berdasarkan uji DMRT pada $\alpha=0.05$. 


\section{Persentase Gabah Isi Per Malai (\%)}

Hasil uji DMRT pada pengaruh mandiri perlakuan pupuk terhadap persentase gabah isi padi gogo lokal Wakawondu (Tabel 9) menunjukkan rata-rata nilai tertinggi pada perlakuan kombinasi pupuk $(76,46 \%)$ dan tidak berbeda nyata dengan perlakuan $100 \%$ pupuk organik $(73,64 \%)$ dan $100 \%$ pupuk anorganik $(76,25 \%)$. Rata-rata persentase gabah isi terendah diperoleh pada $\mathrm{P} 0$ $(66,54 \%)$ dan berbeda nyata dengan perlakuan lainnya. Hal ini disebabkan karena pemberian kombinasi perlakuan pupuk organik bokashi $50 \%$ dan anorganik (NPK) 50\% secara nyata dapat meningkatkan persentase gabah isi. Hal ini tidak berbeda dengan pemberian $100 \%$ pupuk organik bokashi dan $100 \%$ pupuk anorganik (NPK). Kombinasi aplikasi pupuk organik dan anorganik dapat mengurangi tingkat penerapan setiap jenis pupuk, meningkatkan efisiensi penggunaan unsur hara tanaman, mengurangi pencucian unsur hara, sehingga meningkatkan komponen hasil (Usman et al., 2015). Hal ini juga didukung dengan temuan Brar et al. (2015) bahwa penggunaan terintegrasi pupuk anorganik bersama dengan pupuk organik $(100 \%$ NPK+FYM) meningkatkan kondisi fisik tanah seperti KTK dan $\mathrm{pH}$ menghasilkan produksi hasil yang lebih tinggi. Aplikasi pupuk organik dan anorganik serta kombinasi keduanya dalam tanah dapat meningkatkan unsur $\mathrm{K}$ tersedia dalam tanah ( Reddy et al., 2021), sehingga meningkatkan kualitas hasil gabah. Penggunaan pupuk organik dalam jangka panjang dapat memperbaiki kualitas biji padi gogo yang lebih baik dan menjaga kesehatan tanah dan lingkungan serta meningkatkan aktivitas enzimatik dari tanah (Kuziemska et al., 2020). Asupan nutrisi yang bersumber dari bahan organik bokashi dan anorganik sangat penting untuk fotosintesis terutama pada fase pembentukan dan pengisian biji. Sebaliknya, terbatasnya unsur hara dalam tanah dapat menyebabkan terhambatnya proses fotosintesis sehingga menyebabkan rendahnya persentase gabah isi.

Tabel 9. Hasil uji pengaruh mandiri perlakuan pupuk terhadap persentase gabah isi per malai (\%) padi lokal Wakawondu

\begin{tabular}{lc}
\hline Perlakuan & Rata-rata Persentase Gabah Isi (\%) \\
\hline Tanpa Pupuk & $66,54^{\mathrm{b}}$ \\
$100 \%$ pupuk organik & $73,64^{\mathrm{a}}$ \\
$100 \%$ pupuk anorganik & $76,55^{\mathrm{a}}$ \\
Kombinasi (50\% organik $+50 \%$ anorganik) & $76,52^{\mathrm{a}}$ \\
\hline
\end{tabular}

Keterangan : Angka yang diikuti huruf yang tidak sama pada kolom $(a, b)$ yang sama berbeda nyata berdasarkan uji DMRT pada $\alpha=0.05$.

\section{Bobot 1000 Butir Gabah (g)}

Hasil uji DMRT pengaruh mandiri perlakuan sistem budidaya terhadap bobot 1000 butir padi gogo lokal Wakawondu (Tabel 10) menunjukkan menunjukkan rata-rata tertinggi pada sistem budidaya gogo rancah yaitu $27,42 \mathrm{~g}$ dan terendah pada sistem budidaya gogo yaitu $24,87 \mathrm{~g}$. Hal ini disebabkan karena tanaman padi yang ditanam secara gogo rancah memiliki kondisi air yang cukup sehingga dapat mencukupi kebutuhan air pada saat pembungaan dan pengisian biji. Kurangnya suplai air selama proses pengisian bulir padi dapat mempengaruhi bobot 1000 butir gabah. Pratama et al. (2017) menjelaska bahwa proses pengisian bulir membutuhkan air yang cukup, suplai air yang tidak dapat menyebabkan proses pengisian bulir tidak akan terjadi. Menurut Donggulo et al. (2017) bahwa tinggi rendahnya berat 1000 butir padi bergantung pada bahan kering dalam gabah yang dihasilkan dari proses fotosintesis yang dimanfaatkan untuk pengisian bulir.

Pengaruh mandiri perlakuan pupuk rata-rata tertinggi pada perlakuan $100 \%$ pupuk anorganik $(28,08 \mathrm{~g})$ dan tidak berbeda nyata dengan $100 \%$ pupuk organik $(27,73 \mathrm{~g})$ dan kombinasi $50 \%$ organik $+50 \%$ anorganik $(26,31 \mathrm{~g})$. Bobot 1000 butir gabah berhubungan dengan panjang malai dan total gabah per malai. Berdasarkan hasil yang diperoleh, pemberian $100 \%$ pupuk organik pada tanah dapat menghasilkan panjang malai dan total gabah yang tinggi. Hal ini disebabkan karena pemberian pupuk anorganik sebagai komplemen dapat meningkatkan produktivitas tanah dan tanaman secara berkelanjutan (Warankar et al., 2020). Hal ini dapat menunjang proses fotosintesis sehingga mampu menghasilkan gabah yang baik. Proses fotosintesis akan berjalan dengan baik karena teredianya unsur $\mathrm{P}$ dalam tanah sehingga meningkatkan hasil fotosintat yang ditransfer ke 
dalam biji. Bobot gabah padi sangat berhubungan erat dengan proses fotosintesis pada daun (Azalika et al., 2018) karena hasil fotosintat dapat mempengaruhi ukuran dan bentuk gabah. Seiring bertambahnya jumlah gabah isi menyebabkan kepadatan gabah per malai sehingga mempengaruhi ukuran dan bentuk gabah.

Berdasarkan hasil uji pengamatan pertumbuhan dan hasil padi gogo lokal Wakawondu meunjukkan bahwa penggunaan isolat rizobakteri KNW11 mampu meningkatkan hasil padi lokal Wakawondu dan menekan terjadinya penyakit hawar daun bakteri (Xanthomonas campestris oryzae $p v$. oryzae) terutama pada saat awal pembungaan sampai pengisian biji padi. Hal ini menyebabkan daun tanaman secara maksimal melakukan fotosintesis dengan baikl. Rizobakteri tersebut diyakini memiliki keunggulan, seperti mampu memproduksi hormon IAA, melarutkan fosfat dan memfikasi nitrogen sehingga berimplikasi pada peningkatan pertumbuhan dan hasil padi gogo lokal (Sutariati dan Wahab, 2012; Afa et al., 2020; dan Guyasa et al. (2018).

Tabel 10. Hasil uji pengaruh mandiri perlakuan sistem budidaya dan pupuk bobot 1000 butir gabah (g) padi lokal Wakawondu

\begin{tabular}{lc}
\hline Perlakuan & Rata-rata Bobot 1000 bulir $(\mathrm{g})$ \\
\hline Gogo & $24,87^{\mathrm{b}}$ \\
Gora Rancah & $27,42^{\mathrm{a}}$ \\
\hline Tanpa Pupuk & $22,46^{\mathrm{b}}$ \\
$100 \%$ pupuk organik & $27,73^{\mathrm{a}}$ \\
$100 \%$ pupuk anorganik & $28,08^{\mathrm{a}}$ \\
Kombinasi (50\% organik $+50 \%$ anorganik) & $26,31^{\mathrm{a}}$ \\
\hline Keterangan : Angka yang diikuti huruf yang tidak sama pada kolom $(\mathrm{a}, \mathrm{b})$ yang sama berbeda nyata
\end{tabular}

\section{KESIMPULAN}

Padi lokal Wakawondu yang diberi rizobakteri indigenous KNW11 sangat sesuai dibudidayakan secara gogo rancah dan direkomendasikan menggunakan $100 \%$ pupuk anorganik (NPK). Budidaya padi pada sistem budidaya gogo direkomendasikan menggunakan $100 \%$ pupuk organik bokashi kirinyuh. Kombinasi sistem gogo rancah dan pemberian 100\% pupuk anorganik dapat meningkatkan tinggi tanaman, jumlah daun, jumlah anakan produktif dan panjang malai. Pemberian $100 \%$ pupuk organik bokashi pada sistem budidaya gogo dapat meningkatkan jumlah daun dan jumlah anakan produktif.

\section{REFERENSI}

Adesemoye, A.O., M. Obin, and E.O. Ugoji. 2008. Comparison of plant growth promoting with Pseudomonas aeruginosa and Bacillus subtilis in three vegetables. Braz. J. Microbiol. 39:423-426.

https://doi.org/10.1590/S151783822008000300003 .
Afa, L.O. A.A. Anas, dan A. Hamzah. 2018. Produksi Bebebrapa Kultivar Padi Gogo (Oryza sativa L.) Lokal Sulawesi TenggaraIndonesia pada Dua Sistem Budidaya. Laporan Penelitian Nasional Institusi. Universitas Halu Oleo. 142 p.

Afa, M., G.R. Sadimantara, N.M.Rahni and G.A.K. Sutariati. 2020. Isolation and Characterization Of Rhizobacteria From Local Shallots Rhizosphere As Promoting Growth Of Shallot Rhizosphere As Promoting Growth Of Shallot. International Journal of Scientific dan Technology Research. IJSTR. Vol. 9(3). ISSN:22778616.

http://www.ijstr.org/finalprint/mar2020/Isolat ion-CharacterizationOf-Rhizobacteria-From-

Local-Shallots Rhizosphere-As-PromotingGrowth-OfShallot-allium-Ascalonicum-L.pd.

Agegnehu, G., A.M. Bass, P.N. Nelson, and M.I. Bird. 2016. Benefits of biochar, compost and biochar compost for soil quality, yield and greenhouse gas emissions in a tropical 
agricultural soil. Sci Total Environ. 543:295306.

doi: 10.1016/j.scitotenv.2015.11.054. PMID: 26590867.

Arsanti. 2017. Karakterisasi Rizobakteri Asal Tanaman Padi gogo Lokal Sultra yang Berpotensi sebagai pemacu Pertumbuhan Tanaman. Skripsi, Universitas Halu Oleo, Kendari.

Azalika, P.R., Sumardi, dan Sukisno. 2018. Pertumbuhan dan Hasil Padi Sirantau Pada Pemberian Beberapa Macam dan Dosis Pupuk Kandang. JIPI, 20 (1), Hal:26-32.

DOI: https://doi.org/10.31186/jipi.20.1.26-32

Barus, J. 2008. Respon Tanaman Padi Terhadap Pemupukan $\mathrm{P}$ pada Tingkat Status Hara $\mathrm{P}$ Tanah yang Berbeda. Jurnal Akta Agrosia, 8(2): 52-55.

Brar, B.S., J. Singh, G. Singh, and G. Kaur. 2015. Effects of Long Term Application of Inorganic and Organic Fertilizers on Soil Organic Carbon and Physical Properties in Maize Wheat Rotation. Agronomy. Vol. 5(2):220-238.

DOI:10.3390/agronomy5020220

Donggulo, C.V., M.I. Lapanjang, and U. Madem. 2017. Growth and Yield of Rice under Different Jajar Legowo System and Planting Space. J. Agroland. 24(1):27-35.

https://core.ac.uk/download/pdf/296928751.pdf

Guyasa, I., G.R Sadimantara, A. Khaeruni, G.A.K Sutariati. 2018. Isolation Of Bacillus Spp And Pseudomonas Fluorescens From Upland Rice Rhizosphere And Its Potential As Plant Growth Promoting Rhizobacteria For Local Upland Rice. Bioscience Research, 15 (4): (3231-3239).

https://www.isisn.org/BR15(4)2018/32313239-15(4)2018BR18-430.pdf

Han, S.H., J.Y. An, J. Hwang, S.B. Kim, and B.B. Park. 2016. The Effects Of Organic Manure and Chemical Fertilizer On The Growth and Nutrient Concentrations Of Yellow Poplar (Liriodendron tulipifera Lin.) in a Nursery System, Forest Science and Technology, 12(3): $137-143$.

DOI:10.1080/21580103.2015.1135827.

Hüve, K., I. Bichele, H. Kaldmäe, Rasulov, B., F. Valladares, and Ü. Niinemets. 2019. Responses of Aspen Leaves to Heatflecks:
Both Damaging and Non-Damaging Rapid Temperature Excursions Reduce Photosynthesis. Plants, 8(6), 145. https://www.ncbi.nlm.nih.gov/pmc/articles/P MC6630322/ doi: 10.3390/plants8060145

Kadidaa, B., G.R. Sadimantara, Suaib, L.O. Safuan, and Muhidin. 2017. Genetic Diversity of Local Upland Rice (Oryza sativa L.) Genotypes Based On Agronomic Traits and Yield Potential In Marginal Land of North Buton Indonesia. Asian Journal of Crop Science, 9(4):109-117.

DOI:10.3923/ajcs.2017.109.117.

Kuziemska, B., A. Wysokiński, and P. Klej. 2020. Effect of different zinc doses and organic fertilization on soil's enzymatic activity. J.Elem. 25:3:1089-1099.

DOI:10.5601/jelem.2020.25.1.1927

Laila, R.A, B. Zainuddin, dan M. Usman. 2017. Respon Pertumbuhan dan Hasil Tanaman Padi (Oryza sativa L.) Terhadap Kebutuhan Nitrogen Menggunakan Bagan Warna Daun. Jurnal Agroland 24(2).

http://jurnal.untad.ac.id/jurnal/index.php/AG ROLAND/article/view/8782

Li, R., R. Tao, N. Ling, and G. Chu. 2017. Chemical, organic, and bio-fertilizer management practices effect on soil physicochemical property and antagonistic bacteria abundance of cotton field: implications for soil biological quality. Soil and Tillage Research 167: 30-38. DOI:10.1016/j.still.2016.11.001.

Makarim, A.K. dan E. Suhartatik. 2009. Morfologi dan Fisiologi Tanaman Padi. Balai Besar Penelitian Tanaman Padi. 50 halaman. https://www.litbang.pertanian.go.id/special/p adi/bbpadi_2009_itkp_11.pdf.

Mondal, S., M. Mallikarjun, M. Ghosh, D.C. Ghosh, and J. Timsina. 2016. Influence Of Integrated Nutrient Management (INM) on Nutrient Use Efficiency, Soil Fertility And Productivity Of Hybrid Rice. Archives of Agronomy and Soil Science. 62 (11),15211529. DOI: 10.1080/03650340.2016.1148808.

Mungai, N.W., A. Bationo, and B. Waswa. 2009. Soil Properties as Influenced by Soil Fertility Management in Small Scale Maize Farms in Njoro, Kenya. Journal of Agronomy, 4: 131136. https://doi.org/10.3923/ja.2009.131.136 
Norsalis, E. 2011. Padi Sawah dan Padi Gogo Tinjauan Secara Morfologi, Budidaya dan Fisiologi. p 33-43.

Padmanabha, I.G., I.D.M Arthagama, dan I.N Dibia. 2014. Pengaruh Dosis Pupuk Organik dan Anorganik terhadap Hasil Padi (Oriza sativa L.) dan Sifat Kimia Tanah pada Inceptisol Kerambitan Tabanan. E-Jurnal Agroekoteknologi Tropika 3(1). 41-50. https://ojs.unud.ac.id/index.php/

JAT/article/download/7966/6037/.

Pratama, A. Idwar dan A.E Yulia. 2017. Pengaruh Tegangan Air Terhadap Efisiensi Pemupukan N, P, dan K Pada Tanaman Padi Gogo Lokal Varietas Kalpatali Di Tanah Ultisol. JOM Faperta UR Vol. 4 No.1.

https://jom.unri.ac.id/index.php/JOMFAPER TA/article/view/16299

Rachmadani, N.W., Koesriharti, dan M. Santoso. 2014. Pengaruh Pupuk Organik Dan Pupuk Anorganik Terhadap Pertumbuhan Dan Hasil Tanaman Buncis Tegak (Phaseolus vulgaris L.). Jurnal Produksi Tanaman, 2 (6): 443-452. http://protan.studentjournal.ub.ac.id/index .php/protan/article/view/129.

Reddy, N.S., W. P. Badole, M.B. Nirgulkar, and K.D. Bhoyar. 2021. Impact of Organic, Inorganic and Integrated Nutrient Management Practices On Carbon Pool and Nutrient Availability of Perennial, Annual and Seasonal Crops Grown Innagpur District. Int.J.Curr.Microbiol.App.Sci. 10(1):1739-1751. doi: https://doi.org/10.20546/ijcmas.2021.100 1.204 .

Roidah, I.S. 2013. Manfaat Penggunaan Pupuk Organik untuk Kesuburan Tanah. Jurnal Universitas Tulungagung Bonorowo, 1(1):3042. https://balittro.litbang.pertanian.go.id.

Sadimantara, G.R. dan Muhidin. 2012. Daya Hasil Beberapa Kultivar Padi Gogo Lokal Asal Sulawesi Tenggara pada Cekaman Kekeringan. Jurnal Agroteknos, 2(3): 121125.

Sadimantara, G.R., A. Widarsi, dan Muhidin. 2011. Pengujian Kadar Antosianin Padi Gogo Beras Merah Hasil Koleksi Plasma Nutfah Sulawesi Tenggara. Crop Agro, 4(2):43-48. https://adoc.pub/pengujian-kadar-antosianinpadi-gogo-beras-merah-hasil-koleka3c88584 d77c92ce1 be8d5f43f58920941394.html
Sarwanto, S. Samudin dan A. Ete. 2018. Karakterisasi Beberapa Kultivar Padi Gogo Lokal. Agrotekbis: 6(2): 274- 284. http://jurnal.faperta.untad.ac.id/index.php/agr otekbis/article/view/358

Sikuku, P.A., G.W. Netondo, J.C. Onyango and D.M. Musyimi. 2010. Chlorophyll fluorescence, protein and chlorophyll content of three NERICA rainfed rice varieties under varying irrigation regimes. ARPN J. Agr. Biol. Sci. 5:19-25.

https://repository.maseno.ac.ke/handle/12345 $6789 / 2563$.

Susanto, A., A.E. Prasetyo, H. Priwiratama, dan M. Syarovi. 2020. Laju fotosintesis pada tanaman kelapa sawit terinfeksi karat daun Cephaleuros virescen. Jurnal Fitopatologi Indonesia, 16(1), 21-29.

https://doi.org/10.14692/jfi.16.1.21-29

Sutariati G.A.K., dan Wahab. 2012. Karakter Fisiologis dan Kemangkusan Rizobakteri Indigenus Sulawesi Tenggara sebagai Pemacu Pertumbuhan tanaman Cabai. J. Hort, 22(1): 57-64.

http://ejurnal.litbang.pertanian.go.id/index.ph $\mathrm{p} /$ jhort/article/view/405.

Sutariati, G.A.K., Khaeruni, A. dan Madiki, A. 2011. Bio-Matriconditioning Benih dengan Rizobakteri untuk meningkatkan Mutu Fisiologi Benih Sorgum (Shorgum bicolor L.). Jurnal Agroteknos. Vol. 1 No. 1 Hal. 2126. ISSN: 2087-7706. https://adoc.pub/biomatriconditioning-benih-dengan-rizobakteriuntuk-meningk.html.

Tombesi, S., I. Cincera, T. Frioni, V. Ughini, M. Gatti, A. Palliotti, and S. Poni. 2019. Relationship among night temperature, carbohydrate translocation and inhibition of grapevine leaf photosynthesis. Environmental and Experimental Botany, 157:293-298. https://doi.org/10.1016/j.envexpbot.2018.10.0 23.

Tufaila, M., Yusrina and S. Alam. 2014. Pengaruh Pupuk Bokashi Kotoran Sapi Terhadap Pertumbuhan dan Produksi Padi Sawah pada Ultisol Puosu Jaya Kecamatan Konda, Konawe Selatan. J. Agroteknos, 4 (1). http://ojs.uho.ac.id/index.php/agroteknos/arti cle/download/201/142

Usman M., V.U. Madu, and G. Alkali. 2015. The Combined Use of Organic and Inorganic 
Fertilizers for Improving Maize Crop Productivity in Nigeria. IJSRP. ISSN. 22503153. Volume 5( 10): ISSN 2250-3153. http://www.ijsrp.org/research-paper1015/ijsrp-p4698.pdf.

Usman, A., Rusdiansyah, dan Sadarudin. 2004. Pertumbuhan dan Hasil Tanaman Padi pada Lahan Sawah Tadah Hujan Akibat Umur Bibit dan Jarak Tanam yang Berbeda. Jurnal Budidaya Pertanian, 10(2):104-112.

Warankar, V.V., Y.S. Chavan, A.N. Jadhav, M.E. Bahiram, A.M. Gaikwad, V.G. Chavan, V.A. Rajemahadik, V.V. Sagavekar, and S.A. Chavan. 2020. Nutrient Management in kharif Rice through Inorganic and Organic Sources for Enhancing Productivity and Profitability in konkan Region of
Maharashtra. Int.J.Curr.Microbiol. App. Sci, 9 (12): 355-364.

DOI: https://doi.org/10.20546/ijcmas.2020.91 2.045

Yullianida, Suwarno, Ardie SW, Aswidinnoor H. 2014. Uji Cepat Toleransi Tanaman Padi Terhadap Cekaman Rendaman pada Fase Vegetatif. Jurnal Agron. Indonesia 42 (2) : 89-95.

https://media.neliti.com/media/publications/1 63387-none-c607e342.pdf.

Zang, H., Tan, G.L., Xue, Y.G., Liu, L.J. dan Yang, J.C. 2010. Changes in grain yield and morphological an Physiological charcteristic during 60-year evolution of Japonica rice cultivars in Jiangsu. Acta Agronomica Sinica 36:133-140. 